\title{
Biomass and diversity of dry alpine plant communities along altitudinal gradients in the Himalayas
}

\author{
Tsewang Namgail • Gopal S. Rawat • \\ Charudutt Mishra $\cdot$ Sipke E. van Wieren • \\ Herbert H. T. Prins
}

Received: 9 May 2010/Accepted: 21 February 2011 / Published online: 3 June 2011

(C) The Author(s) 2011. This article is published with open access at Springerlink.com

\begin{abstract}
A non-linear relationship between phytodiversity and altitude has widely been reported, but the relationship between phytomass and altitude remains little understood. We examined the phytomass and diversity of vascular plants along altitudinal gradients on the dry alpine rangelands of Ladakh, western Himalaya. We used generalized linear and generalized additive models to assess the relationship between these vegetation parameters and altitude. We found a humpshaped relationship between aboveground phytomass and altitude. We suspect that this is engendered by low rainfall and trampling/excessive grazing at lower slopes by domestic livestock, and low temperature and low nutrient levels at higher slopes. We also found a unimodal relationship between plant species-richness and altitude at a single mountain as well as at the scale of entire Ladakh. The species-richness at the single mountain peaked between 5,000 and 5,200 m, while it peaked between 3,500 and 4,000 $\mathrm{m}$ at entire Ladakh level.
\end{abstract}

T. Namgail · C. Mishra

Snow Leopard Trust and Nature Conservation Foundation, 3076/5, IV-Cross, Gokulam Park, Mysore 570002,

Karnataka, India

T. Namgail · S. E. van Wieren · H. H. T. Prins

Resource Ecology Group, Department of Environmental

Sciences, Wageningen University, Droevendaalsesteeg 3a,

Lumen-100, 6708 PB Wageningen, The Netherlands

G. S. Rawat

Wildlife Institute of India, P.O. Box 18,

Dehradun 248 001, Uttaranchal, India

Present Address:

T. Namgail ( $\square)$

USGS, Western Ecological Research Center,

San Francisco Bay Estuary Field Station,

505 Azuar Drive, Vallejo, CA 54592, USA

e-mail: namgail@ncf-india.org
Perhaps biotic factors such as grazing and precipitation are, respectively, important in generating this pattern at the single mountain and entire Ladakh.

Keywords Aboveground biomass - Altitude ·

Mid-altitude effect · Rapoport's rule - Species richness ·

Vascular plants

\section{Introduction}

The world's mountainous regions host at least third of the plant species diversity, and altitudinal gradients in these regions are the most powerful 'natural experiments' for testing ecological and evolutionary responses of biota to geophysical influences (Körner 2007). In high mountain systems, plant species were earlier thought to be more diverse at lower slopes and decrease with altitude because of declining temperature. This gradient in species richness in mountainous regions was thus thought to be analogous to the Rapoport's latitudinal rule (Stevens 1992), but more recent studies have contested this view (Rahbek 1995), demonstrating that species diversity peaks somewhere in the middle of the altitudinal gradient (Rahbek 1995, 1997).

Altitude is thus one of the most important factors in determining the phytodiversity, because it strongly influences the length of growing season associated with temperature, especially in the temperate region, and the availability of soil moisture and nutrients (Soethe et al. 2008). Nevertheless, hitherto most of the studies on the subject have been carried out at single spatial scales in the tropics and temperate regions (Aiba and Kitayama 1999; Bhattarai et al. 2004; Grytnes and Vetaas 2002; Moser et al. 2008), and there is limited information from the alpine systems, which in fact are ideal for studying biodiversity patterns along altitudinal 
gradients as the environmental conditions in these systems can change within short distances (Dufour et al. 2006). Moreover, it is crucial to investigate the relationship at different spatial scales, as different geophysical factors may become important at different spatial scales.

Further, the pattern of phytomass along an altitudinal gradient is understood far less than the pattern of phytodiversity. Phytomass is an important component of the global carbon cycle, and has implications for the distribution and abundance of herbivores (Olff et al. 2002). Therefore, it is crucial to understand the abundance patterns of plants in grazing ecosystems. Although the spatial pattern of net primary productivity was studied on the Tibetan plateau (Yang et al. 2009) and other natural grassland ecosystems (Epstein et al. 1997; Jobbagy et al. 2002; Sala et al. 1988), the pattern of aboveground phytomass along an altitudinal gradient has not been explored explicitly, as alluded to earlier. There is, however, a general belief that phytomass changes inversely with altitude in the tropical and temperate regions, perhaps due to the fact that trees are larger at the lower slopes of a mountain, but whether this applies to treeless, alpine environments with minimal precipitation is not clear.

The Ladakh region of the Indian Trans-Himalaya $\left(32^{\circ}-\right.$ $36^{\circ} \mathrm{N}$ and $75^{\circ}-80^{\circ} \mathrm{E}$ ) includes high altitude cold, dry ecosystems (desert, steppe and scrub; Rawat and Adhikari 2005a). The region has unrivaled topographic variations encompassing an altitudinal range from 2,800 to $7,670 \mathrm{~m}$ asl, which provides an array of habitats for alpine plants. Kachroo et al. (1977) reported 611 vascular plants from the region, representing 190 genera and 51 families. The distribution and abundance of these plants, however, remain poorly understood. Hitherto only one study has been carried out on their distributional pattern along an altitudinal gradient, but only in one part of the region (Klimes 2003). The rapid change in altitudinal gradient, even at short distances, makes Ladakh an ideal place for studying the vegetation pattern along altitude to understand the vegetation dynamics associated with biotic and abiotic factors that vary with height.

Therefore, capitalizing on the huge altitudinal gradient of the alpine steppes of Ladakh, we asked (a) what is the relationship between aboveground phytomass and altitude in dry alpine environments? (b) How plant species richness varies along altitude at different spatial scales? In addition to these, we also examined the vegetation cover in relation to altitude and slope angle.

\section{Materials and methods}

Study area

Ladakh is situated in the Indian Trans-Himalaya (Fig. 1), covering an area of ca. $80,000 \mathrm{~km}^{2}$. It is unique in terms of

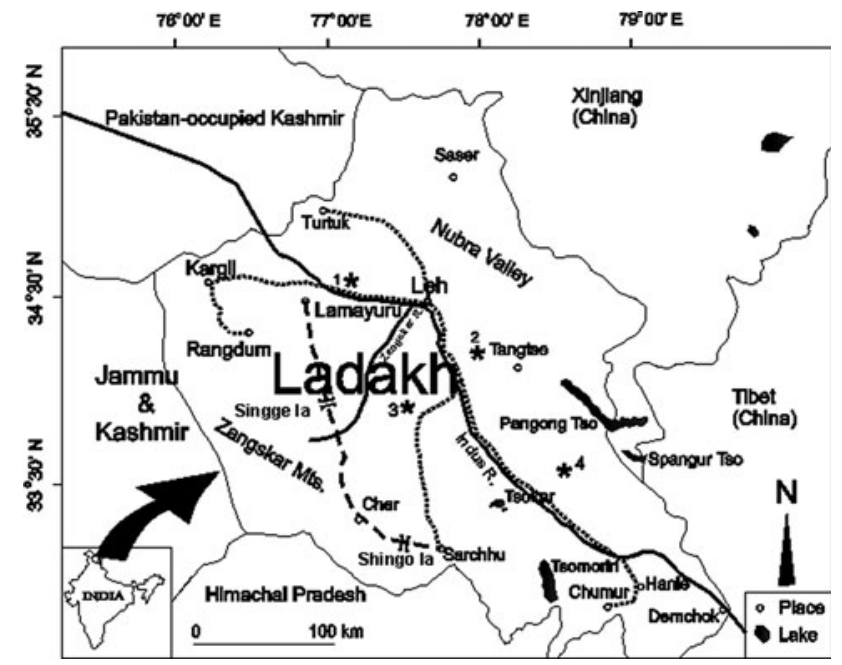

Fig. 1 The Ladakh region with different study sites (1 proposed Ridzong Wildlife Sanctuary, 2 Hemis National Park, 3 proposed Gya-Miru Wildlife Sanctuary, 4 Changthang Wildlife Sanctuary), and the transects (broken line: trail = vegetation cover; dotted line: road $=$ plant species richness) marked

geography, geology and edaphic features (Kachroo et al. 1977). The vegetation is relatively diverse due to these physical features and the great altitudinal range. Ladakh's topography is characterized by high, steep and rugged mountains separated by deep valleys in which the Indus and Zangskar Rivers, and their tributaries flow (Namgail 2009a). The climate is characterized by long, cold periods without favourable conditions for growth in winter and short growth season in summer, and there is a marked diurnal variation in temperature. The soil is nutrient-poor, consisting of sandy clay and at places coarse gravel or murram, and is more alkaline in some parts. The region supports very sparse vegetation consisting of low shrubs, stunted grasses and herbs (Chaurasia and Singh 1997; Rawat and Adhikari 2005b) largely due to the short growing season, harsh climatic conditions, low rainfall and poor soil.

Ladakh is bounded by the Great Himalayan Range on the south and the Karakoram Range on the north. The former range blocks most of the monsoon bearing clouds, making the region arid (Namgail 2009a). Winter precipitation is mostly in the form of snow, which is associated with the extra-tropical disturbances of mid-latitudes known as "Western Disturbances" (Dhar and Mulye 1987). The south-western part of the region gets slightly more precipitation compared to the east and the north-east, and thus is greener (Hartmann 1983). The vegetation of eastern Ladakh is largely dominated by hemicryptophytes, followed by Therophytes and Chamaephytes (Klimes 2003). Champion and Seth (1968) described the vegetation of Ladakh as 'dry alpine scrub' that is characterized by 
complete absence of forest cover, except relict patches of juniper Juniperus polycarpos stands in some parts of Zangskar and Sham. Other prominent trees are willow Salix spp. and poplar Populus spp. that are restricted mainly to cultivated areas along rivers.

Ladakh harbours a relatively rich assemblage of wild large herbivores such as Tibetan gazelle Procapra picticaudata, Tibetan antelope Pantholops hodgsoni, Blue sheep Pseudois nayaur, Ladakh urial Ovis vignei vignei, Asiatic ibex Capra ibex siberica, Tibetan argali Ovis ammon hodgsoni, Tibetan wild ass or Kiang Equus kiang and wild yak Bos mutus, but their numbers are low (Namgail et al. 2010a). The mountain slopes (or the rangelands) are also used by the local communities for grazing a variety of domestic livestock including yak, sheep, goat, horse, donkey, cow and dzo (hybrid between yak and cow). However, the population of domestic ungulates (c. 200,000) is almost ten times higher than that of their wild counterparts (Namgail 2009b). Pashmina or cashmere wool, obtained from a local breed of goat called Changra, is the most valuable product from these rangelands (Namgail et al. 2010b). The local people in the western part are agro-pastoralists with major emphasis on agriculture, while those in the east are mainly nomadic pastoralists (Namgail et al. 2007a).

\section{Sampling methods}

\section{Phytomass}

The data for assessing the relationship between aboveground phytomass and altitude were collected between July and September 2007 with maximum (88\%) collected in August, the peak growth season. Sampling was done in four protected areas (see Fig. 1): the proposed Ridzong Wildlife Sanctuary $\left(34^{\circ} 20^{\prime} \mathrm{N}, 77^{\circ} 04^{\prime} \mathrm{E}\right.$; elevational range sampled $=3,595-4,850 \mathrm{~m}$ asl), Hemis National Park $\left(34^{\circ} 06^{\prime} \mathrm{N}, \quad 77^{\circ} 23^{\prime} \mathrm{E} ; 3,445-4,900 \mathrm{~m}\right.$ asl), the proposed Gya-Miru Wildlife Sanctuary $\left(33^{\circ} 40^{\prime} \mathrm{N}, \quad 77^{\circ} 47^{\prime} \mathrm{E}\right.$; 3,750-4,515 $\mathrm{m}$ asl) and the Changthang Wildlife Sanctuary $\left(33^{\circ} 19^{\prime} \mathrm{N}, 78^{\circ} 29^{\prime} \mathrm{E} ; 3,905-5,100 \mathrm{~m}\right.$ asl). We walked along the valley bottoms, and placed a vertical transect at every $200 \mathrm{~m}$ alternatively on either side of a valley, starting at the valley-bottom. Along each of the vertical transects, we sampled phytomass in $2 \times 2 \mathrm{~m}$ plots at $50-\mathrm{m}$ elevational intervals. Vegetation was clipped to the ground level in these quadrats and stored in paper bags. The plant material was then sun-dried and weighed to the nearest $0.1 \mathrm{~g}$ to estimate aboveground phytomass. We avoided sampling in areas near cultivated fields and riverine scrub, which generally support much higher aboveground phytomass due to woody shrubs.
Phytodiversity

Sampling for assessing the relationship between plant species richness and altitude needed to be done separately, as we could not identify many plant species collected for determining phytomass, as they were dried for weighing. Sampling for phytodiversity at the single mountain (hereafter referred to as local scale) was done during peak standing biomass in the Hanle Valley of eastern Ladakh. Two vertical transects (each covering 1,000 m:4,500 $5,500 \mathrm{~m}$ asl with no variation in aspect) were walked with a GPS on two opposite sides of the mountain. Using a modified line-intercept method (Mueller-Dombois and Ellenberg 1974), we placed two 20-m lines (except at six locations where only one was placed), perpendicular to the $1,000-\mathrm{m}$ transects and extending to opposite directions, at 50-m elevational intervals along the transects. We divided the lines into $0.5-\mathrm{m}$ segments, and recorded plant species (or any other substrate such as soil, rock, etc.) intercepting each segment. Since the distribution and diversity patterns of graminoids and non-graminoids along an altitudinal gradient could have important implications for the distribution of herbivores (Hanle Valley is the prime area for the Tibetan gazelle, which feeds largely on non-graminoids), the species richness of these functional groups were recorded separately to see if they differ in their distributional patterns along an altitudinal gradient.

Data for assessing the relationship between plant species richness and altitude at the entire Ladakh level (hereafter referred to as regional scale; see Fig. 1) were collected between July and September 2007. However, the relationship between species richness and altitude at the this scale was assessed using the total plant species richness as there were not enough data in the two functional groups: graminoids and non-graminoids. We drove from Rangdum in the west to Hanle in the east (approx. $500 \mathrm{~km}$; altitudinal range, 2,800-6,000 m asl), and Turtuk in the north to Sarchhu in the south (approx. $300 \mathrm{~km}$; altitudinal range, 2,860$5,460 \mathrm{~m}$ asl), at an average speed of $50 \mathrm{~km} / \mathrm{h}$, stopping every $1 \mathrm{~h}$ and laying $20 \mathrm{~m}$ lines on randomly selected slopes following the same methodology as described above. When the road was rough, which slowed us down, we increased the time interval between samplings to avoid spatial autocorrelation. We also avoided sampling on human-modified landscape (cultivated, construction sites, etc.). Plants were identified in the field using field guides (e.g., Aswal and Mehrotra 1994; Kachroo et al. 1977; Polunin and Stainton 1990). Those species that could not be identified in the field were brought to the Herbarium at the Wildlife Institute of India for identification and verification.

To assess the relationship between plant species richness and climate at the regional scale, we obtained climatic variables: precipitation in the wettest quarter of the year 
(abbreviated in the figures as PreWetQ), mean annual precipitation (AnnPrec), precipitation in the driest quarter (PreDriQ), annual mean temperature (AnMeTe), mean temperature of the coldest quarter (MTeCoQ), mean temperature of the warmest quarter $(\mathrm{MTeWaQ})$ at $1 \mathrm{~km}^{2}$ resolution from the WorldClim database (Hijmans et al. 2005). These variables were extracted from all the transect locations in a GIS environment (ArcView 9; ESRI 1996).

\section{Vegetation cover}

We also visually estimated vegetation cover (in cover classes of $10 \%$ ) in association with altitude and slope. We walked slowly (about $1 \mathrm{~km} / \mathrm{h}$ ) and scanned randomly located slopes every $5 \mathrm{~h}$ for vegetation cover. We explored the area between Lamayuru and Sarchhu in the Zangskar Mountains. First we walked along the upper reaches of the Zangskar River, over the Sisir La (La means pass in Ladakhi; 4,700 m) and Singge La $(4,825 \mathrm{~m})$, and then along the Tsarap, Lingti and Kargyak Rivers at about 4,200-4,800 m, over the Shingo La $(5,050 \mathrm{~m})$, and finally along the Sangpo and Jankar Rivers at about 4,500 and 4,700 m, respectively (see Fig. 1). Locations and altitudes were determined through a global positioning system (Garmin GPS 12) and an altimeter (Origo Accusense Multi-sensor). In total we walked about $250 \mathrm{~km}$ at an average altitude of 4,800 $\mathrm{m}$ asl.

\section{Statistical analysis}

We regressed aboveground phytomass against altitude to assess the relationship between these two variables. We pooled data from the 3 months as there was no significant difference in phytomass amongst the months $(t=0.474$, $P=0.637)$. To determine the relationship between species richness and altitude, first we analyzed the data using generalized linear models, but when assessed the difference between a logarithmic link and an identity link function (assuming normal distributions of error) by drawing diagnostic Q-Q plots (Q stands for quantile) of the residual variation, the Poisson model had a slightly better fit, perhaps due to fewer counts. Therefore, we used generalized additive models (GAM) assuming a Poisson distribution. Within the GAM framework, we used a cubic smooth spline so that any abrupt change in vegetation distribution could be captured (Hastie and Tibshirani 1990). This is especially appropriate because Ladakh represents two biogeographic provinces: Tibetan Plateau in the east and the Hindukush-Karakoram Mountains (including Ladakh and Zangskar Ranges) in the west (Namgail 2009a), and there might be abrupt changes in floral community patterns. Graminoids and non-graminoids were analyzed separately at the local scale, as alluded to earlier.
Subsequently, we performed regression analysis to evaluate the influence of climate on plant species richness at the regional scale. Further, we used canonical correspondence analysis (CCA) to explore the relationship between plant species distribution and climatic variables, putting all species in a continuous environmental perspective. This method is useful in measuring the amount of variation in the species distribution data that can be explained by different explanatory variables. This analysis was carried out using the CANOCO software version 4.5 (Ter Braak 1986).

\section{Results}

Phytomass

Aboveground phytomass from 65 quadrats at randomly placed transects in the four protected areas was measured. These protected areas spanned various topographical and altitudinal ranges. The mean phytomass (dry weight) in the proposed Ridzong Wildlife Sanctuary was $3.9 \mathrm{~g} \mathrm{~m}^{-2}$ ( $n=12$ quadrats), Hemis National Park was $4.3 \mathrm{~g}$ $\mathrm{m}^{-2} \quad(n=13)$, Changthang Wildlife Sanctuary was $5.6 \mathrm{~g} \mathrm{~m}^{-2}(n=13)$, and that in Gya-Miru Wildlife Sanctuary was $6.4 \mathrm{~g} \mathrm{~m}^{-2}(n=27)$. The mean phytomass (dry weight) for the entire region was $5.4 \mathrm{~g} \mathrm{~m}^{-2}$ (range 1-16.4 g). The regression analysis showed a hump-shaped relationship between aboveground phytomass and altitude $(F=9.803, P=0.003$; Fig. 2).

Phytodiversity

\section{Local scale (Hanle valley)}

Plant species from 74 20-m lines were recorded to assess the relationship between species richness and altitude at the

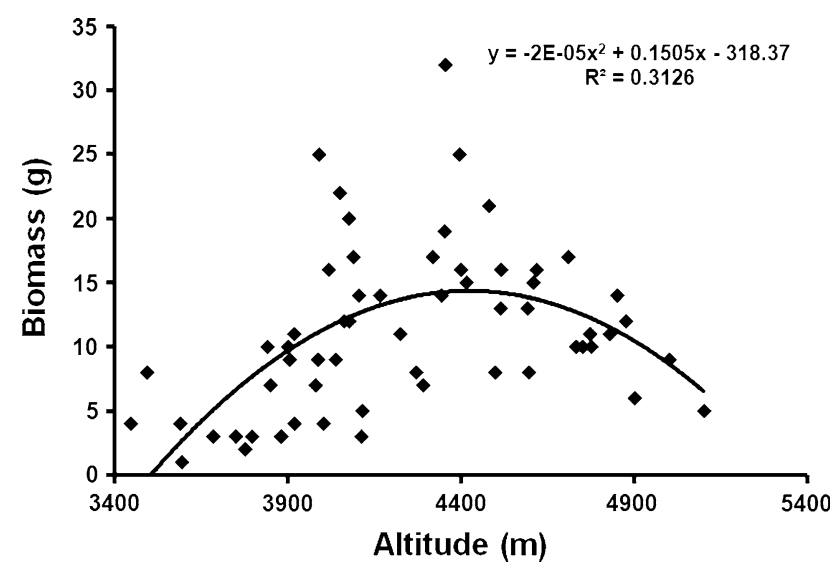

Fig. 2 Non-linear relationship between aboveground phytomass (dry weight) and altitude in Ladakh 
local scale. A total of 28 plant species were recorded during sampling at this spatial scale. Both graminoid richness $\left(R^{2}=3.6\right.$; Fig. 3a) and non-graminoid richness $\left(R^{2}=3.5\right)$ had hump-shaped relationships with altitude (Fig. 3b). The smooth splines with four degrees of freedom for these functional groups indicated sharp humps in species richness between 5,000 and 5,200 m. For the graminoids, there was also a sharp increase in species richness before it slumps (Fig. 3c), while for non-graminoids the increase and decrease were more gradual (Fig. 3d).

\section{Regional scale (entire Ladakh)}

We sampled plants from 55 20-m lines spread all over Ladakh. A total of 141 plant species were recorded, and twenty-seven plant species were encountered most frequently during the sampling at this scale (Table 1). The plant species richness had a hump-shaped relationship with altitude (Fig. 4a), and peaked at around 4,000 m asl (Fig. 4b). Precipitation was the most important climatic determinant of plant distributions (Table 2; Fig. 5). The
CCA showed that amongst the most commonly encountered species, Artemisia maritima, Ephedra gerardiana, Echinops cornigerus and Lindelofia longiflora occur in areas with high precipitation, whereas Krascheninnikovia ceratoides, Tanacetum tibeticum and Astragalus rhizanthus occur in drier habitats (Fig. 5).

Vegetation cover

Vegetation cover varied as a function of altitude and slope angle. It peaked in areas at an altitude of $4,200 \mathrm{~m}$, and zero to $10^{\circ}$ slope angle (Fig. 6). Low altitudes $(<3,600 \mathrm{~m})$ and very high areas $(>5,000 \mathrm{~m})$ had very little vegetation cover $(<10 \%)$. Similarly, very steep areas $\left(>45^{\circ}\right)$ had little vegetation cover.

\section{Discussion}

The hump-shaped relationship between aboveground phytomass and altitude is in contrary to our expectation.
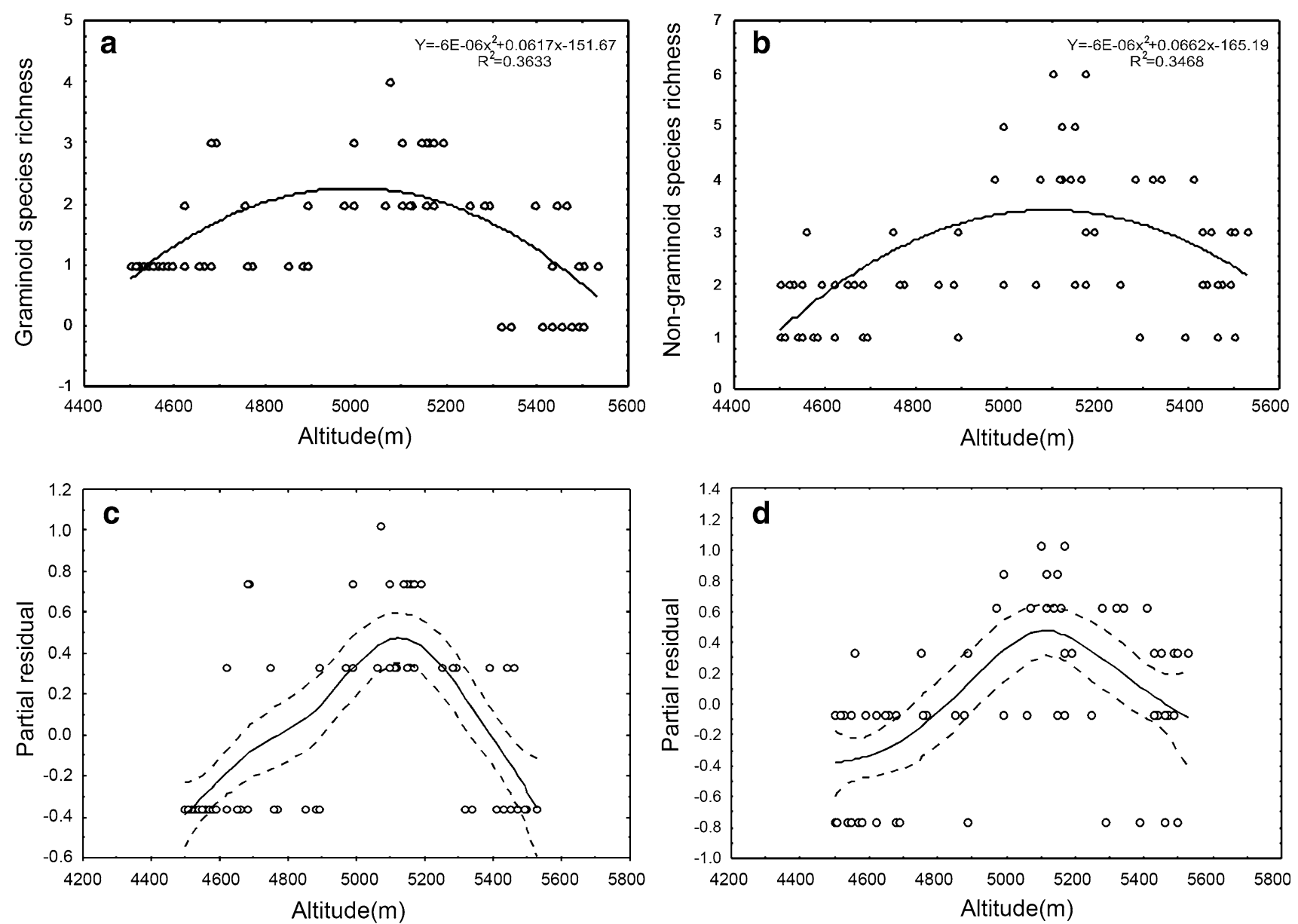

Fig. 3 Relationship between graminoid $(\mathbf{a}, \mathbf{c})$ and non-graminoid $(\mathbf{b}, \mathbf{d})$ species richness and altitude at a local scale (Hanle Valley). In $\mathbf{c}, \mathbf{d}$ the solid lines are the cubic smooth splines and the dashed lines are $95 \%$ confidence limits 
Table 1 Plant species that were encountered in more than $50 \%$ of the transects at the regional scale

\begin{tabular}{|c|c|c|}
\hline Species & Family & Abbr. in $\mathrm{CCA}$ \\
\hline Aconogonum tortuosum & Polygonaceae & Aco-tor \\
\hline Potentilla fruticosa & Rosaceae & Pot-fru \\
\hline Saussurea taraxicifolia & Compositae & Sau-bra \\
\hline Saussurea bracteata & Compositae & Sas-tar \\
\hline Echinops cornigerus & Compositae & Ech-cor \\
\hline Artemisia brevifolia & Compositae & Art-bre \\
\hline Artemisia maritima & Compositae & Art-mar \\
\hline Waldheimia stoliczkai & Compositae & Wal-sto \\
\hline Tanacetum tibeticum & Compositae & Tan-tib \\
\hline Cicer microphyllum & Papilionoideae & Cic-mic \\
\hline Caragana versicolor & Papilionoideae & Car-ver \\
\hline Acantholimon lycopodiodes & Plumbaginaceae & Aca-lyc \\
\hline Androsace mucronifolia & Primulaceae & And-muc \\
\hline Ephedra gerardiana & Ephedraceae & Eph-ger \\
\hline Lindelofia longiflora & Boraginaceae & Lin-lon \\
\hline Rheum webbianum & Polygonaceae & Rhe-web \\
\hline Dracocephalum heterophyllum & Labiateae & Dra-het \\
\hline Heracleum pinnatum & Umbelliferae & Her-pin \\
\hline Geranium sibiricum & Gentianaceae & Ger-sib \\
\hline Krascheninnikovia ceratoides & Chenopodiaceae & Kra-cer \\
\hline Arenaria bryophylla & Caryophyllaceae & Are-bry \\
\hline Oxytropis microphylla & Leguminosae & Oxy-mic \\
\hline Astragalus rhizanthus & Papilionoideae & Ast-rhi \\
\hline Pedicularis cheilanthifolia & Scrophulariaceae & Ped-che \\
\hline Carex melanantha & Cyperaceae & Car-utr \\
\hline Stipa orientalis & Gramineae & Sti-ori \\
\hline Elymus nutans & Gramineae & Ely-nut \\
\hline
\end{tabular}

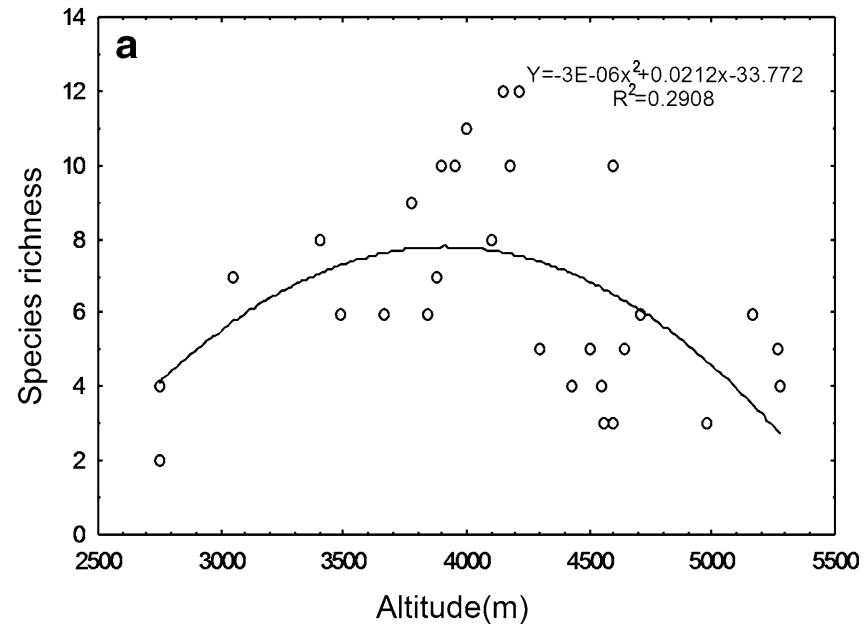

Generally, one would expect a linear negative relationship between phytomass and altitude due to declining temperature and nutrients with altitude (Rastetter et al. 2004). The low phytomass at high altitude in the study area is explicable, but it is difficult to explain the low phytomass at lower altitudes. It is possible that trampling and overgrazing by domestic livestock at the lower slopes deplete plant resources. These lower slopes in the alpine steppes of Ladakh are grazed more intensively (Namgail et al. 2007b), and are trampled by the animals while moving to and from the high pastures on a daily basis. This is tenable because livestock grazing is known to decrease plant biomass in other central Asian alpine rangelands (Zhou et al. 2006). Further, when the data for the Changthang Wildlife Sanctuary, with the highest population of livestock in Ladakh (Namgail et al. 2007a), were analysed separately, the hump became more prominent $\left(R^{2}=0.76\right)$. Therefore, the influence of livestock grazing on spatial pattern of plant abundance needs to be investigated further as the livestock population is growing rapidly in the region (Namgail et al. 2007a).

The hump-shaped relationship between vascular plant species-richness and altitude in Ladakh conforms to the general trend observed in other mountainous regions (Bhattarai et al. 2004; Rahbek 1995). At the local scale, i.e., on the single mountain, such a trend could be attributed to competitive exclusion of plants by few dominant species at the valley bottoms and the mountain-tops (see Bruun et al. 2009). For instance, selective grazing of the more palatable species by several types of livestock (Namgail et al. 2007a) may have given a competitive edge to few grazing-tolerant species at the lower slopes (see Olff and

Fig. 4 Relationship between plant species richness and altitude at a regional scale (entire Ladakh). In $\mathbf{b}$ the solid line is the cubic smooth spline and the dashed lines are the $95 \%$ confidence limits 
Table 2 The regression of climatic variables and plant species richness

\begin{tabular}{lrlrrr}
\hline Variable & \multicolumn{1}{c}{ Beta } & Standard error beta & \multicolumn{1}{c}{$B$} & Standard error $B$ & $t(24)$ \\
\hline PreWetQ & -2.317 & 0.419 & -0.010 & 0.002 & -5.520 \\
AnnPre & 2.278 & 0.390 & 0.004 & 0.000 & 5.839 \\
MTeWaQ & 0.791 & 0.750 & 0.003 & 0.002 & $<0.001$ \\
AnMeTe & -0.892 & 0.709 & -0.003 & 0.002 & 0.001 \\
\end{tabular}

PreWetQ Precipitation in the wettest quarter of the year, AnnPrec mean annual precipitation, $M T e C o Q$ mean temperature of the coldest quarter, AnMeTe annual mean temperature

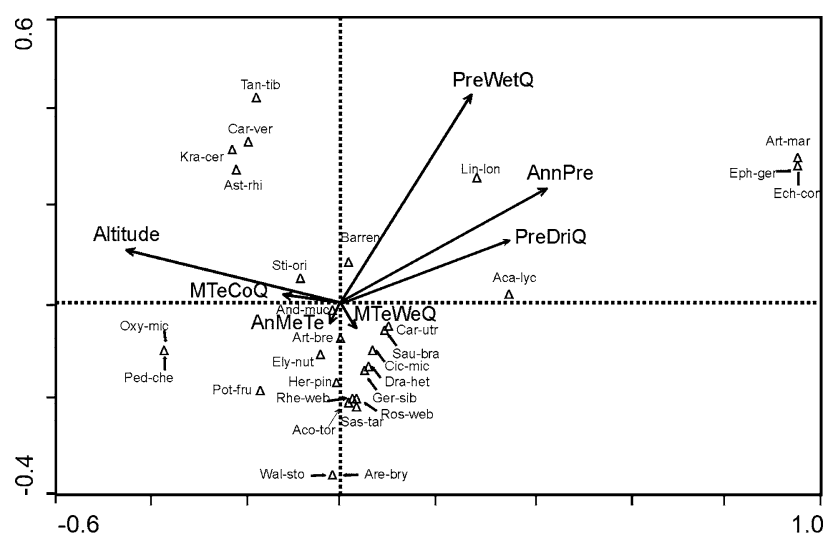

Fig. 5 CCA ordination of some common plant species in Ladakh and the environmental variables. See Table 1 for species identity. PreWetQ precipitation in the wettest quarter of the year, AnnPrec mean annual precipitation, $\operatorname{PreDri} Q$ precipitation in the driest quarter, AnMeTe annual mean temperature, $M T e C o Q$ mean temperature of the coldest quarter, $M T e W a Q$ mean temperature of the warmest quarter)

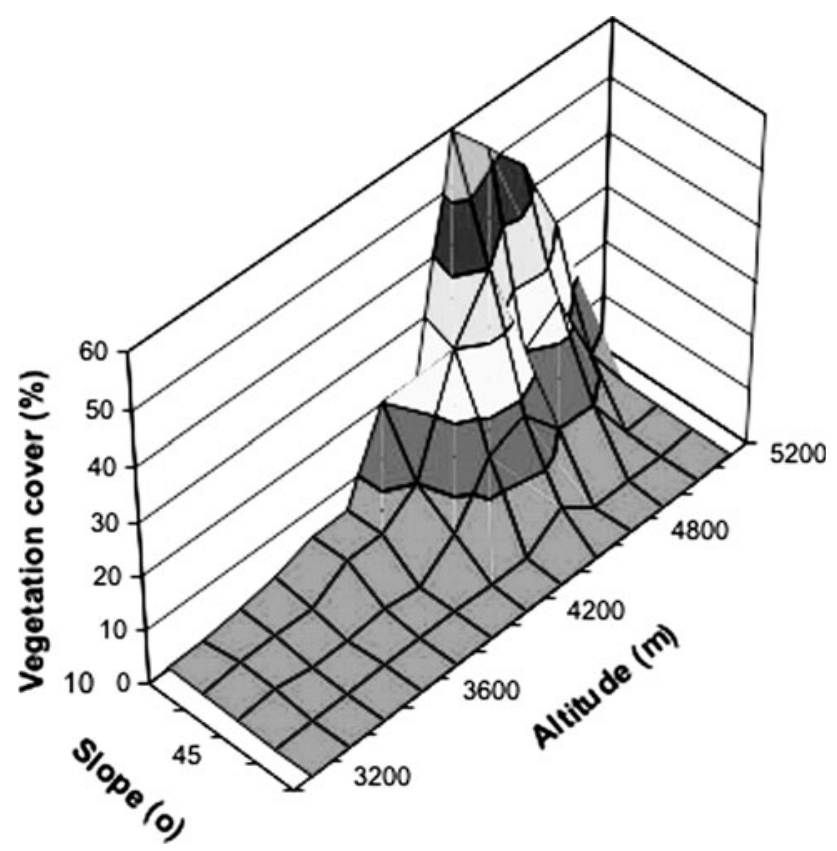

Fig. 6 Vegetation cover (\%) as a function of slope angle and altitude during peak growth season in the mountainous region of Ladakh, India
Ritchie 1998), while cold-tolerant species may usurp the resources and outcompete other species at high altitudes (see Klimes 2003; Rawat and Adhikari 2005b). The plant communities below $4,600 \mathrm{~m}$ were largely dominated by less palatable species like the Tanacetum gracile and Stipa spp. (again pointing at heavy grazing in areas where people live), while plant communities above $5,100 \mathrm{~m}$ were dominated by cold-resistant plants like Delphinium sp., Thylacospermum sp. and Saussurea spp.

The low plant species richness at lower slopes could also be attributed to soil erosion, for pastoralists uproot plants such as Krascheninnikovia ceratoides and Caragana versicolor from these slopes (Rawat and Adhikari 2005b). Caragana, a leguminous plant is known to enhance soil fertility as its root-nodules have nitrogen-fixing bacteria ( $\mathrm{Lu}$ et al. 2009), and it also helps in retaining moisture in the soil. Thus, the effect of overexploitation of this plant on phytodiversity in the region needs to be investigated as anthropogenic pressures are increasing on the rangelands (Mishra and Rawat 1998; Saberwal 1996). During the present investigation, we found the lowest vegetation cover on steep slopes $\left(>45^{\circ}\right)$, which could also be attributed to soil erosion.

At the regional scale, the hump-shaped relationship could be attributed to less number of species at lower altitudes (southwestern Ladakh) due to high precipitation, and again less species at higher altitudes (eastern Ladakh) due to low precipitation, which may have resulted in less soil moisture and thus less vegetation. As a resource, water, if measured appropriately, could have a humpshaped relationship with plant species richness (Pausas and Austin 2001). The lower valleys of western Ladakh get more precipitation than the higher plateau in the east (Hartmann 1983), as the Himalayan mountains in the western part of Ladakh are lower, and thus are perhaps less of a barrier to the monsoon clouds. In any case, both regression and CCA showed that precipitation is an important factor in explaining the variability in plant species distribution and richness data. Therefore, although biotic factors such as herbivores might determine the vascular plant species richness at a local scale like Hanle Valley, climatic factors become more important 
determinants of plant species richness pattern at a regional scale (see Lenoir et al. 2008).

Acknowledgments This study was financially supported by the Wageningen University, the Rufford Small Grants Foundation, and the Wildlife Conservation Society. We thank Karma Sonam for his assistance in the field. We thank the Director, Wildlife Institute of India for all the help to TN during his stay in Dehradun. We thank two anonymous reviewers for their critical comments on an earlier draft of the manuscript.

Open Access This article is distributed under the terms of the Creative Commons Attribution Noncommercial License which permits any noncommercial use, distribution, and reproduction in any medium, provided the original author(s) and source are credited.

\section{References}

Aiba S-i, Kitayama K (1999) Structure, composition and species diversity in an altitude-substrate matrix of rain forest tree communities on Mount Kinabalu, Borneo. Plant Ecol 140:139-157

Aswal BS, Mehrotra BN (1994) Flora of Lahaul-Spiti Bishen Singh Mahendra Pal Singh, Dehradun, India

Bhattarai KR, Vetaas OR, Grytnes JA (2004) Fern species richness along a central Himalayan elevational gradient. Nepal J Biogeog $31: 389-400$

Bruun HH, Moen J, Virtanen R, Grytnes J-A, Oksanen L, Angerbjörn A, Ezcurra E (2009) Effects of altitude and topography on species richness of vascular plants, bryophytes and lichens in alpine communities. J Veg Sci 17:37-46

Champion FW, Seth SK (1968) A revised survey of the forest types of India Manager. Government of India Press, Nasik

Chaurasia OP, Singh B (1997) Cold desert plants DRDO [Defence Research and Development Organization]. Field Research Laboratory, Leh

Dhar ON, Mulye SS (1987) A brief appraisal of precipitation climatology of the Ladakh region. In: Pangtey YPS, Joshi SC (eds) Western Himalaya: environment, problems and development. Gyanodaya Prakashan, Nainital

Dufour A, Gadallah F, Wagner HH, Guisan A, Buttler A (2006) Plant species richness and environmental heterogeneity in a mountain landscape: effects of variability and spatial configuration. Ecography 29:573-584

Epstein HE, Lauenroth WK, Burke IC (1997) Effects of temperature and soil texture on ANPP in the US great plains. Ecology 78:2628-2631

ESRI (1996) ArcView GIS. The Geographic Information System for Everyone Environmental Systems Research Institute, New York

Grytnes JA, Vetaas OR (2002) Species richness and altitude: a comparison between null models and interpolated plant species richness along the Himalayan altitudinal gradient, Nepal. Am Nat 159:294-304

Hartmann H (1983) Pflanzengesells chaften entlang der Kashmirroute in Ladakh. Jb Ver Schutz Bergwelt 13:1-37

Hastie TJ, Tibshirani RJ (1990) Generalized additive models. Chapman \& Hall, London

Hijmans RJ, Cameron SE, Parra JL, Jones PG, Jarvis A (2005) Very high resolution interpolated climate surfaces for global land areas. Int J Climatol 25:1965-1978

Jobbagy EG, Sala OE, Paruelo JM (2002) Patterns and controls of primary production in the Patagonian steppe: a remote sensing approach. Ecology 83:307-319
Kachroo P, Sapru BL, Dhar U (1977) Flora of Ladakh: an ecological and taxonomic appraisal Bishen Singh Mahendra Pal Singh, Dehradun, India

Klimes L (2003) Life-forms and clonality of vascular plants along an altitudinal gradient in E Ladakh (NW Himalayas). Bas Appl Ecol $4: 317-328$

Körner C (2007) The use of 'altitude' in ecological research. Trends Ecol Evol 22:569-574

Lenoir J, Gegout JC, Marquet PA, de Ruffray P, Brisse H (2008) A significant upward shift in plant species optimum elevation during the 20th century. Science 320:1768-1771

Lu YL, Chen WF, Han LL, Wang ET, Chen WX (2009) Rhizobium alkalisoli sp. nov., isolated from Caragana intermedia growing in saline-alkaline soils in the north of China. Int J Syst Evol Microbiol 59:3006-3011

Mishra C, Rawat GS (1998) Livestock grazing and biodiversity conservation: comments on Saberwal. Cons Biol 12:712-717

Moser G, Röderstein M, Soethe N, Hertel D, Leuschner C (2008) Altitudinal changes in stand structure and biomass allocation of tropical mountain forests in relation to microclimate and soil chemistry. In: Beck E, Bendix J, Kottke I, Makeschin F, Mosandl R (eds) Gradients in a tropical mountain ecosystem of Ecuador. Springer, Berlin, pp 229-242

Mueller-Dombois D, Ellenberg H (1974) Aims and methods of vegetation ecology. Wiley, New York

Namgail T (2009a) Geography of mammalian herbivores in the Indian Trans-Himalaya: patterns and processes. Wageningen University, Wageningen

Namgail T (2009b) Mountain ungulates of the Trans-Himalayan region of Ladakh, India. Int J Wilder 15:35-40

Namgail T, Bhatnagar YV, Mishra C, Bagchi S (2007a) Pastoral nomads of the Indian Changthang: production system, land use and socioeconomic changes. Hum Ecol 35:497-504

Namgail T, Fox JL, Bhatnagar YV (2007b) Habitat shift and time budget of the Tibetan argali: the influence of livestock grazing. Ecol Res 22:25-31

Namgail T, van Wieren SE, Mishra C, Prins HHT (2010a) Multispatial co-distribution of the endangered Ladakh urial and blue sheep in the arid Trans-Himalayan mountains. J Arid Environ 74:1162-1169

Namgail T, Van Wieren SE, Prins HHT (2010b) Pashmina production and socio-economic changes in the Indian Changthang: implications for natural resource management. Nat Res Forum 34:222-230

Olff H, Ritchie ME (1998) Effects of herbivores on grassland plant diversity. Trends Ecol Evol 13:261-265

Olff H, Ritchie ME, Prins HHT (2002) Global environmental controls of diversity in large herbivores. Nature 415:901-904

Pausas JG, Austin MP (2001) Patterns of plant species richness in relation to different environments: an appraisal. J Veg Sci 12:153-166

Polunin O, Stainton A (1990) Concise flowers of the Himalaya. Oxford University Press, New York

Rahbek C (1995) The elevational gradient of species richness, a uniform pattern? Ecography 18:200-205

Rahbek C (1997) The relationship among area, elevation and regional species richness in neotropical birds. Am Nat 149:875-902

Rastetter EB, Kwiatkowski BL, Dizes SL, Hobbie JE (2004) The role of down-slope water and nutrient fluxes in the response of Arctic hill slopes to climate change. Biogeochemistry 69:37-62

Rawat GS, Adhikari BS (2005a) Floristics and distribution of plant communities across moisture and topographic gradients in Tso Kar basin, Changthang plateau, eastern Ladakh. Arct Antarct Alp Res 37:539-544

Rawat GS, Adhikari BS (2005b) Millenia of grazing history in eastern Ladakh, India, reflected in rangeland vegetation. In: Proceedings 
of 2nd global mountain biodiversity assessment, La Paz Bolivia. CRC Press, Boca Raton, pp 201-212

Saberwal VK (1996) Pastoral politics: Gaddi grazing, degradation, and biodiversity conservation in Himachal Pradesh, India. Cons Biol 10:741-749

Sala OE, Parton WJ, Joyce LA, Lauenroth WK (1988) Primary production of the central grassland region of the United States. Ecology 69:40-45

Soethe N, Lehmann J, Engels C (2008) Nutrient availability at different altitudes in a tropical montane forest in Ecuador. J Trop Ecol 24:397-406
Stevens GC (1992) The elevational gradient in altitudinal range, an extension of Rapoport's latitudinal rule to altitude. Am Nat 140:893-911

Ter Braak CJF (1986) Canonical correspondence analysis-a new eigenvector technique for multivariate direct gradient analysis. Ecology 67:1167-1179

Yang YH, Fang JY, Pan YD, Ji CJ (2009) Aboveground biomass in Tibetan grasslands. J Arid Environ 73:91-95

Zhou H, Tang Y, Zhao X, Zhou L (2006) Long-term grazing alters species composition and biomass of a shrub meadow on the Qinghai-Tibet Plateau. Pak J Bot 38:1055-1069 